\title{
PERANCANGAN ULANG ANTAR MUKA WEBSITE SEBAGAI MEDIA INFORMASI PERGURUAN TINGGI UNIVERSITAS TELKOM
}

\author{
Mochammad Faizal, Andreas Rio Adriyanto \\ (Email: hai@mf-chan.com) \\ Program Studi S1 Desain Komunikasi Visual \\ Fakultas Industri Kreatif \\ Universitas Telkom \\ Jl. Telekomunikasi no.1, Bandung, Indonesia
}

\begin{abstract}
ABSTRAK
Dewasa ini, teknologi berkembang dengan sangat pesat dengan orang-orang tidak terlepas dari internet. Di dalam internet dikenal suatu media yang bernama website. Idealnya Universitas Telkom harus menerapkan penggunaan website ini untuk menunjang berbagai aktivitas yang terjadi di dalamnya, karena sangat mendukung visi dari Universitas Telkom untuk menjadi "world class university". Namun setelah dilakukan penelitian pendahuluan, telah muncul beberapa permasalahan pada website Universitas Telkom dari segi user interface maupun user experience, khususnya pada versi mobile. Hal-hal tersebut menjadi penting melihat saat ini internet menjadi salah satu sarana dalam mendapatkan informasi terkait perguruan tinggi. Untuk menjawab permasalahan tersebut, akan dilakukan kegiatan perancangan ulang berdasarkan data-data dari studi literatur terkait teori-teori yang relevan, observasi objek visual dari beberapa website sejenis, wawancara kepada ahli UI/UX, serta penyebaran kuesioner kepada target audience dari website tersebut. Setelah data-data terkumpul, maka akan dianalisis melalui matriks perbandingan untuk mendapatkan hasil yang dapat menjadi acuan dari kegiatan perancangan ulang dari antar muka website Universitas Telkom. Harapannya, dengan perancangan ulang user interface terhadap website Universitas Telkom akan tercapai user experience yang baik dari website tersebut, dan juga mendatangkan citra yang baik terhadap perguruan tinggi yang dimaksud.
\end{abstract}

Kata Kunci: media; situs web; Ul; universitas; UX

\begin{abstract}
Today, technology develops rapidly, where people can not be separated from the internet. In the internet, known a media named website, and ideally the Telkom University should implement the use of website to support various activities that take place in it, because it supports the vision of the Telkom University to be a "world class university". However, after a preliminary investigation, it has emerged some problems on the website of the Telkom University in terms of user interface and user experience, especially on mobile version. These things become important, because internet becomes a means to obtain information related to the higher education. To answer these problems, there will be activities redesign based on the data obtained through literature studies related to relevant theories, visual object observation from some similar websites, interviews with UI/UX experts, as well as distributing questionnaires to the target audience of the website itself. Once the data is collected, it will be analyzed through comparative matrix to obtain results that can be the basis of the interface redesign. Hopefully, with the user interface redesign of the Telkom University website will achieve a good user experience, and also bring a good image of the university itself.
\end{abstract}

Keywords: media; Ul; university; UX; website 


\section{PENDAHULUAN}

Dewasa ini, teknologi berkembang dengan sangat pesat. Hampir di setiap kegiatan, orangorang tidak terlepas dari penggunaannya, khususnya internet (interconnected network) yang sangat memudahkan masyarakat untuk berkomunikasi, saling berinteraksi tanpa terkendala dengan batasan jarak dan waktu. Dari berbagai jenis layanan yang tersedia pada internet, dikenal suatu media yang bernama website yakni salah satu bentuk sarana penyampaian informasi secara digital yang dapat dengan mudah diakses melalui perangkat desktop maupun mobile, yang membuat website semakin marak digunakan oleh berbagai macam institusi untuk berbagai macam keperluan didukung dengan perkembangan teknologi yang semakin memudahkan dalam proses pembuatan serta pengelolaannya.

Idealnya perguruan tinggi sudah menerapkan hal tersebut untuk mengikuti perkembangan zaman. Sebagai salah satu universitas yang berbasis ICT (information and communication technology), sudah sepantasnya Universitas Telkom (Tel-U) menerapkan penggunaan website ini untuk menunjang berbagai aktivitas yang terjadi di dalamnya. Di satu sisi, hal tersebut sangat menunjang visi dari Universitas Telkom itu sendiri untuk menjadi "world class university" karena website juga merupakan salah satu alat branding perguruan tinggi tersebut ke ranah nasional maupun internasional.

Namun, pengguna masih mengalami kendala dan menilai user interface dari website Universitas Telkom masih belum baik, yang akan mengarahkan kepada user experience yang buruk. Dari segi user interface, adapun beberapa permasalahan seperti desain yang belum konsisten, belum adanya pencegahan dan penanganan masalah, belum tercapainya kemudahan pengguna dalam mendapatkan informasi yang dibutuhkan, serta belum tercapainya kesederhanaan dalam desain visual. Sedangkan dari sisi user experience, website tersebut belum mencapai kemudahan dalam penggunaannya, belum bisa dianggap mudah dalam memelajarinya, belum tercapainya tingkat efisiensi pengguna, performa sistem yang belum baik, serta terbentuknya ikatan emosional yang negatif pada pengguna, khususnya pada versi mobile dengan mayoritas pengguna menggunakan perangkat mobile.

Hal-hal tersebut menjadi penting, melihat saat ini teknologi internet menjadi salah satu sarana dalam mendapatkan informasi terkait perguruan tinggi, khususnya bagi masyarakat. Website akan menjadi identitas utama sebuah perguruan tinggi dalam ranah cyber media. 
Karena melalui internet masyarakat dapat mencari dan menemukan informasi secara aktual, tanpa terkecuali informasi mengenai sebuah perguruan tinggi. Harapannya, dengan tercapainya user experience yang baik dari website tersebut akan mendatangkan citra yang baik terhadap perguruan tinggi yang dimaksud.

\section{METODE PENELITIAN}

Dalam sebuah karya visual selalu terdapat tiga aspek, yakni aspek pembuat, aspek imaji, dan aspek pemirsa (Rose, 2001 dalam Soewardikoen, 2013:13). Oleh karena itu, penelitian akan dimulai dari studi pustaka untuk mendapatkan teori-teori yang relevan, kemudian aspekaspek karya visual tersebut akan diteliti melalui observasi untuk aspek imaji, wawancara untuk aspek pembuat, serta kuesioner untuk aspek pemirsa.

\section{Studi Pustaka}

Dalam penelitian ini, dilakukan studi pustaka untuk mendapatkan beberapa teori yang dibutuhkan untuk merancang, antara lain sebagai berikut:

1. Komunikasi; merupakan center of interest dalam situasi perilaku manusia, untuk mengalihkan pesan kepada penerima dengan tujuan memengaruhi perilaku tertentu (Miller, 1996 dalam Suryanto, 2015:51). Adapun tiga fungsi utama komunikasi adalah untuk memberikan informasi maupun pengetahuan kepada masyarakat luas, mengajak maupun membujuk konsumen untuk berperilaku sesuai dengan keinginan produsen, serta membuat konsumen dapat mengingat apa yang disampaikan produsen (Widyatama, 2011:43-46).

2. Brand; merupakan tanda yang berupa gambar, nama, kata, huruf-huruf, angka-angka, susunan warna, maupun kombinasi dari unsur-unsur tersebut, yang memiliki daya pembeda dan digunakan dalam kegiatan perdagangan barang atau jasa (UU merek no. 15 tahun 2001). Sedangkan, branding merupakan proses bagaimana membangun perbedaan brand tersebut di dalam benak masyarakat (Adamson, 2006:18).

3. Website; merupakan sebuah lokasi komputer tertentu di internet dengan alamat unik yang disebut URL (uniform resource locator), yang terdiri dari beberapa halaman web terkait, dapat berisi teks, gambar, suara, maupun video (Williams dan Sawyer, 2007:65).

4. Visual; dalam perancangan ini ada enam aspek visual yang diperhatikan meliputi:

- Layout; penataan dan pengaturan teks atau grafik pada halaman yang meliputi penyusunan, pembagian tempat dalam suatu halaman, pengaturan jarak spasi, 
pengelompokan teks dan grafik, serta penekanan pada suatu bagian tertentu (Suyanto, 2009:53).

- Negative space; ruang kosong yang terletak di antara beberapa elemen visual. Dengan ketiadaan konten pada negative space, akan membuat perhatian pembaca lebih tertuju kepada konten yang ada (Cao et al., 2015:7). Negative space dapat berfungsi sebagai pemisah antar elemen visual, sehingga pengguna website dapat membaca informasi yang ditampilkan dengan lebih jelas dan mudah dimengerti.

- Tipografi; sebuah alat komunikasi yang harus dapat berkomunikasi dengan kuat, jelas, dan mudah terbaca (Moholy, 1923 dalam Kusrianto, 2009:191).

- Ilustrasi; seni gambar yang dimanfaatkan untuk memberi penjelasan secara visual yang saat ini tidak lagi hanya berguna sebagai sarana pendukung cerita, namun dapat juga sebagai penghias ruang kosong (Kusrianto, 2009:140).

- Fotografi; seni yang menghasilkan gambar pada film atau permukaan yang dipekakan $(\mathrm{KBBI})$.

- Warna; elemen pelengkap gambar yang mewakili suasana kejiwaan dalam berkomunikasi sehingga mampu merangsang munculnya suatu perasaan (Kusrianto, 2009:46).

5. User interface; merupakan sistem untuk kebanyakan pengguna yang dapat dilihat, didengar, dan disentuh. Tujuan dari desain user interface adalah untuk memudahkan pengguna dalam bekerja dengan komputer sehingga menjadi lebih produktif dan dapat dinikmati, serta tujuan dapat tercapai dengan seefektif mungkin (Galitz, 2007:1-4).

6. User experience; merupakan disiplin ilmu yang berfokus pada perancangan pengalaman yang timbul dari produk tertentu. Untuk merancang sebuah pengalaman, berarti merencanakan tindakan, yang harus menghasilkan perubahan yang direncanakan dalam perilaku dari kelompok sasaran saat berinteraksi dengan produk tersebut (Treder, 2013:19).

\section{Asumsi Penelitian}

Berdasarkan teori-teori yang telah didapat, dapat ditarik asumsi bahwa untuk merancang user interface pada website sebagai media informasi Universitas Telkom untuk meningkatkan user experience harus dimulai dari fungsi dan tujuannya dalam memberikan informasi kepada masyarakat luas, dibalut dengan proses membangun brand di dalam benak masyarakat melalui media website yang informatif dengan visual yang lebih menekankan pada kualitas serta keterbacaan kontennya, sehingga menghasilkan sebuah produk yang 
dapat memudahkan pengguna untuk mencari informasi, dan muncul pengalaman yang baik setelah pengguna menggunakan website tersebut. Adapun kerangka teoretik dapat dilihat pada Gambar 1.

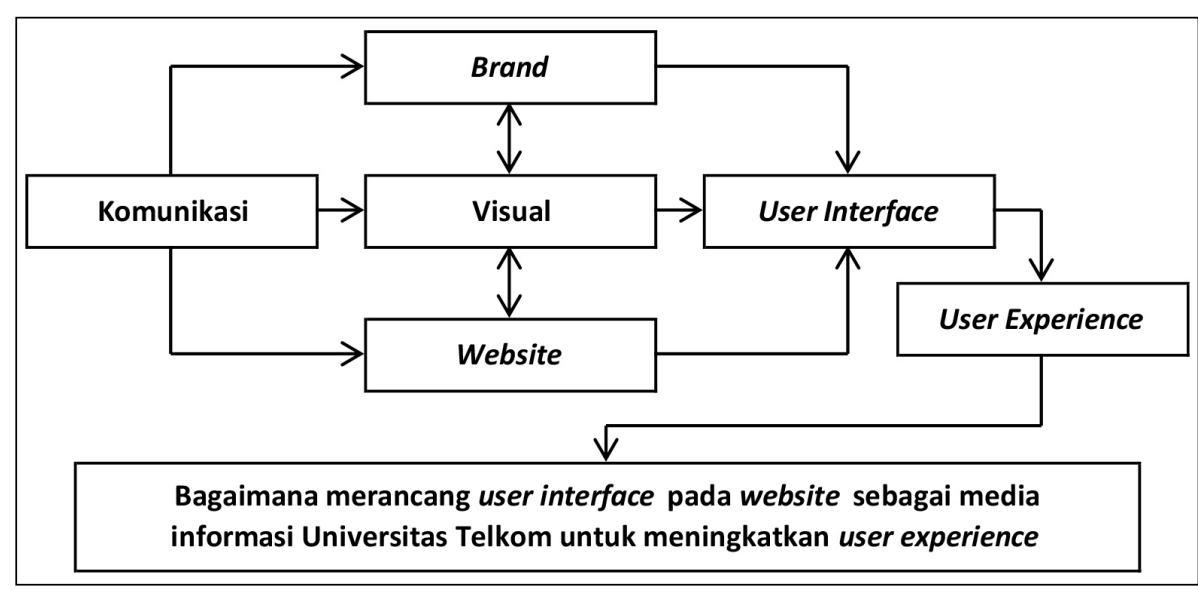

Gambar 1. Kerangka teoretik Sumber: Dokumentasi peneliti

\section{Penelitian Pendahuluan}

Muhammad Fuadit, seorang desainer UI/UX dari Kofera menjelaskan beberapa hal yang harus diperhatikan dalam membangun website dengan nilai UX yang baik di antaranya adalah faktor kecepatan dalam memuat halaman website. Sebuah website sebaiknya dapat dimuat dalam lima hingga enam detik atau pengguna akan merasa bosan jika halaman dimuat lebih dari itu (Faizal et al., 2016:42). Namun, website Universitas Telkom memerlukan sampai dengan 9.7 detik sampai halaman selesai dimuat.

Selain itu, Fuadit juga menyatakan bahwa terdapat permasalahan pada beberapa elemen visual yang terdapat pada UI website Universitas Telkom, di antaranya adalah penggunaan foto disertai tulisan yang tidak konsisten dengan jenis font yang digunakan pada website, penggunaan ilustrasi yang tidak konsisten, kurang sempurnanya pengelompokan informasi yang dapat membingungkan pengguna, serta penggunaan warna yang tidak harmonis.

Dalam penelitian pendahuluan juga telah disebar kuesioner kepada 100 orang mahasiswa Universitas Telkom, untuk meneliti versi desktop maupun mobile dari website Universitas Telkom. Dari hasil kuesioner tersebut, didapat beberapa kendala seperti website yang belum berfungsi dengan sebagaimana mestinya, belum memiliki identitas visual yang jelas, masih sulit untuk dipelajari, masih belum memiliki waktu muat/respon yang cepat, serta mahasiswa belum merasa senang dalam menggunakan website tersebut.

Hasil tersebut menunjukkan bahwa masih dibutuhkan optimalisasi terhadap website 
Universitas Telkom, khususnya untuk versi mobile. Sedangkan, sebanyak $96.67 \%$ mahasiswa perguruan tinggi merupakan pengguna perangkat mobile (Faizal et al., 2016:67). Oleh sebab itu, website perguruan tinggi sudah sepantasnya untuk mudah diakses di berbagai perangkat dengan visual yang estetis dan menarik.

\section{Wawancara Ahli}

Berdasarkan hasil wawancara kepada pihak direktorat Sisfo Universitas Telkom, website Universitas Telkom sudah dua kali berganti desain, berdasarkan keputusan dari pimpinan dan juga dari benchmarking terhadap website lain. Website ini ditujukan kepada calon mahasiswa yang sedang mencari perguruan tinggi untuk melanjutkan studinya. Dari wawancara dengan Farid Naufal Aslam selaku narasumber ahli UI/UX, website Universitas Telkom memiliki beberapa kekurangan pada pengelompokan informasi, konsistensi, hierarki visual, hingga warna yang tidak harmonis. Desain visual dari website memiliki kendala dalam menampilkan terlalu banyak informasi, sementara layout yang digunakan memang sudah responsif, namun seluruh elemen visual yang ada masih belum dapat ditampilkan di setiap perangkat dengan baik.

\section{Observasi Visual}

Website yang diobservasi adalah website dari Universitas Telkom (Gambar 2), Institut Teknologi Bandung (Gambar 3), Universitas Parahyangan (Gambar 4), Universitas Maranatha (Gambar 5), dan Institut Teknologi Sepuluh Nopember (Gambar 6). Hasil observasi menyatakan bahwa dua website yang diteliti memposisikan tombol menu navigasi pada bagian kiri atas yang akan menyulitkan penggunanya, terdapat kesamaan pada objek penelitian, yakni mengaplikasikan Z scanning pattern (Gambar 7) yang akan membuat pembaca melihat secara horisontal pada bagian atas halaman dan ketika mata pembaca sudah mencapai akhir, mereka akan melanjutkan membaca dari bagian bawah kiri, kemudian membaca kembali secara horizontal (Bank dan Cao, 2015:37). Selain itu, website yang dibandingkan telah menerapkan responsive web design dan menggunakan font sans serif. Pada objek penelitian telah terdapat contrast untuk menekankan bagian-bagian tertentu pada halaman, sudah menerapkan negative space yang baik, serta mayoritas website memiliki carousel yang menampilkan kegiatan. Hanya dua website dari objek yang diteliti yang sudah menggunakan prinsip mobile first, namun seluruhnya sudah menggunakan warna brand dari masing-masing perguruan tinggi. 


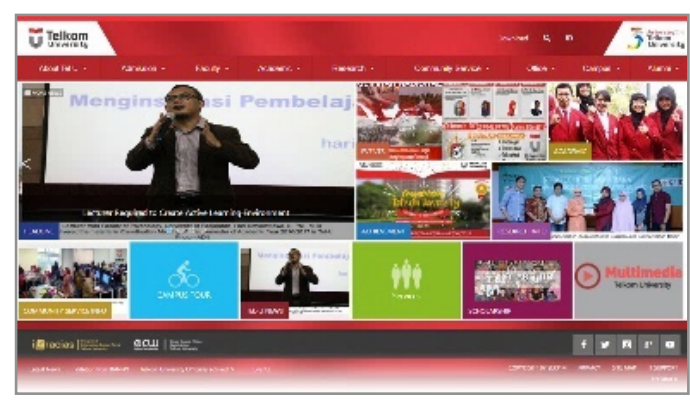

Gambar 2. Website Universitas Telkom Sumber: http://telkomuniversity.ac.id

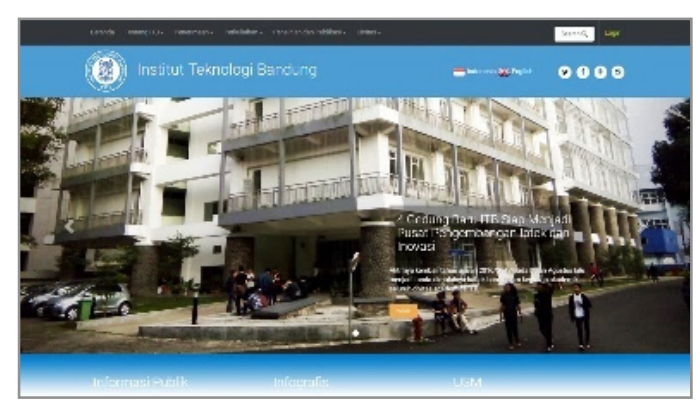

Gambar 3. Website Institut Teknologi Bandung Sumber: https://www.itb.ac.id

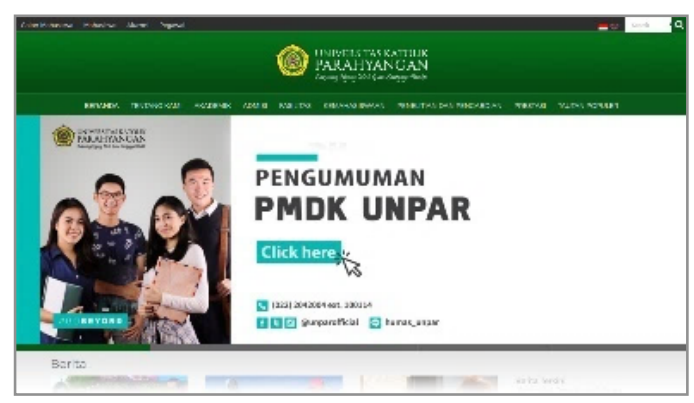

Gambar 4. Website Universitas Katolik Parahyangan Sumber: http://unpar.ac.id

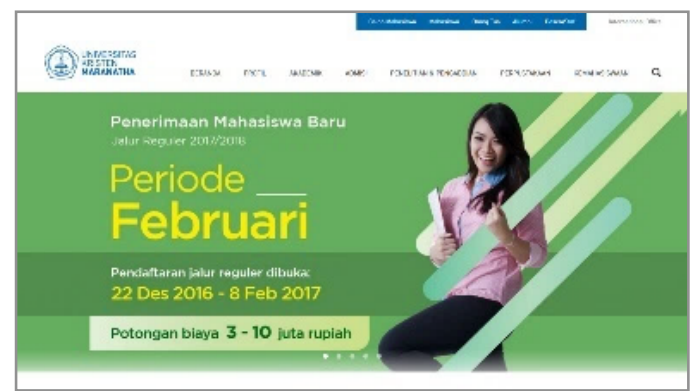

Gambar 5. Website Universitas Kristen Maranatha Sumber: https://www.maranatha.edu 


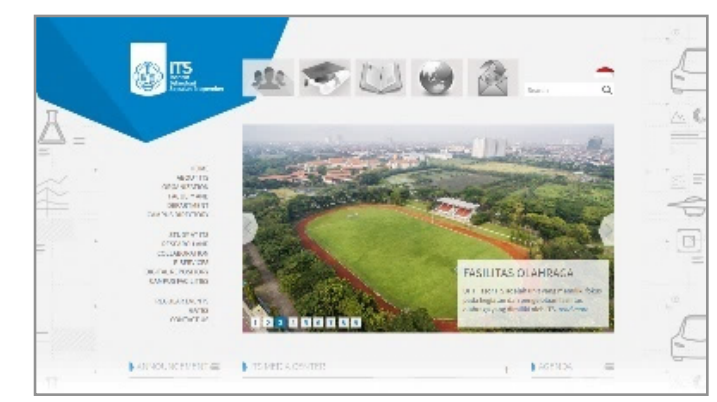

Gambar 6. Website Institut Teknologi Sepuluh Nopember Sumber: http://www.its.ac.id

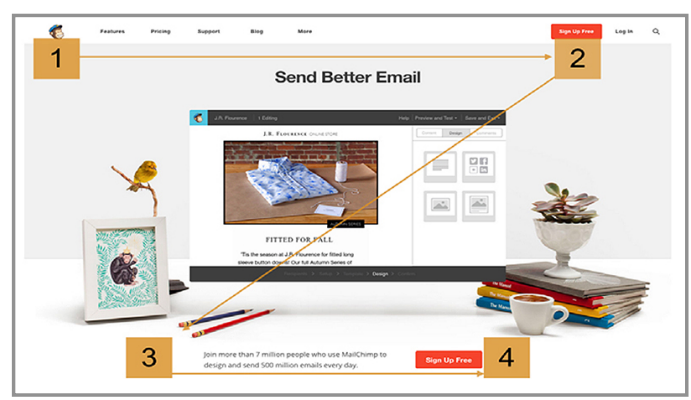

Gambar 7.Z scanning pattern Sumber: Bank dan Cao, 2015

\section{Kuesioner Pemirsa}

Dari 100 kuesioner yang disebarkan kepada siswa/i SMA kelas 12 maupun sederajat yang berada di kota Bandung, 52\% responden menggunakan perangkat desktop. Responden menyatakan bahwa informasi yang paling dicari adalah informasi prodi/fakultas, biaya pendidikan, penerimaan mahasiswa baru, fasilitas yang tersedia, suasana dari lingkungan perkuliahan, profil Universitas Telkom, informasi beasiswa, asrama, galeri foto, serta prestasi yang telah didapatkan oleh Universitas Telkom. Beberapa aspek yang harus dibenahi seperti fasilitas search yang belum sempurna, belum adanya kemudahan dalam menelusuri menu website, pengelompokan informasi pada halaman utama, penerapan komposisi warna, tingkat keterbacaan teks yang ditampilkan, hingga ilustrasi yang digunakan.

\section{PEMBAHASAN}

Hasil analisis dari data-data yang telah terkumpul menggambarkan bahwa kendala pada website Universitas Telkom yakni menyajikan terlalu banyak informasi. Dalam perancangan website yang baru, hendaknya halaman dibuat responsif, serta pemberian kontras yang cukup dapat digunakan pada bagian-bagian yang memerlukan perhatian lebih dari pengguna seperti untuk call to action. Dalam meningkatkan aspek keterbacaan, website Universitas Telkom memerlukan pengelompokan informasi yang lebih sederhana, 
penggunaan tipografi yang lebih sesuai, serta penyesuaian negative space. Hierarki visual juga perlu diperhatikan karena sangat berpengaruh terhadap keterbacaan dan ketercapaian penyebaran informasi. Di samping itu, ada website harus tersedia informasi penting yang dicari calon mahasiswa.

\section{Konsep Perancangan}

Adapun konsep pesan yang ingin disampaikan dalam kegiatan perancangan ini adalah untuk memberikan gambaran jelas dari lingkungan perkuliahan yang terjadi di Universitas Telkom, dikhususkan kepada siswa/i SMA kelas 12 dan sederajat yang ingin/akan melanjutkan studinya ke jenjang perguruan tinggi. Target audience dari kegiatan perancangan ini berasal dari kalangan sosial menengah ke atas yang berada di seluruh wilayah Indonesia, serta menjadikan internet sebagai sumber utama dalam mendapatkan informasi secara aktual.

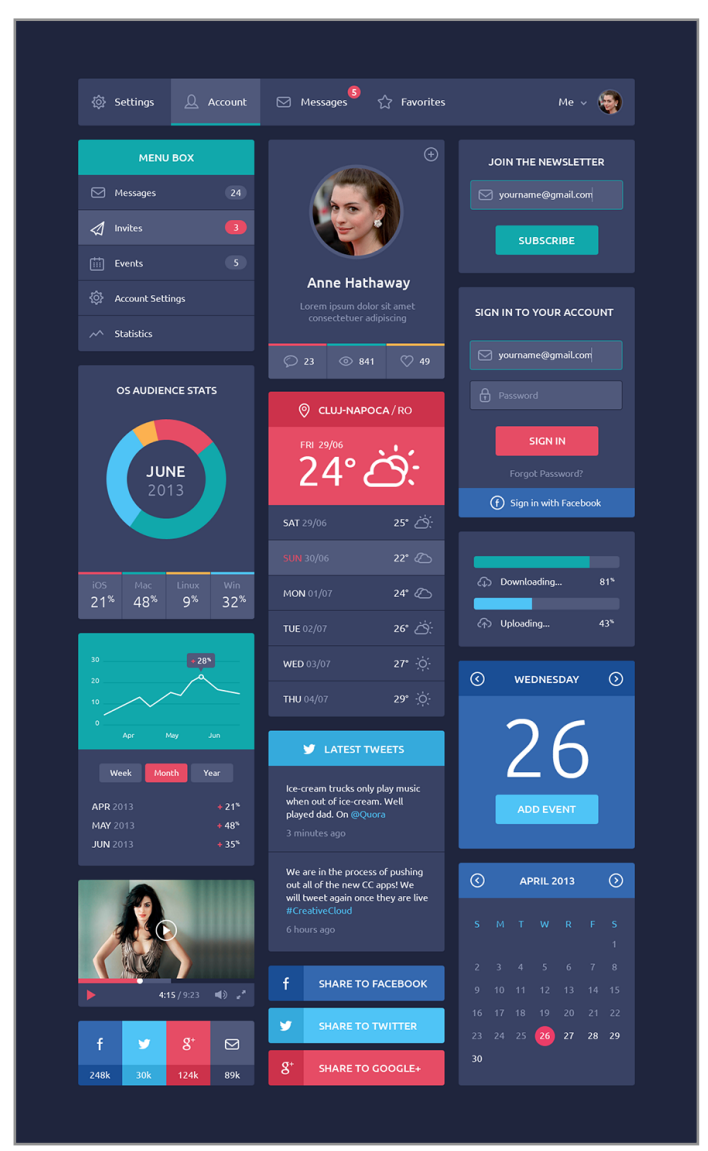

Gambar 8. Flat design

Sumber: https://wdexplorer.com

Untuk konsep kreatif yang akan diterapkan adalah dengan menggunakan desain visual sesuai dengan tren website saat ini, yakni flat design (Gambar 8) untuk meningkatkan nilai 
learnability dari website itu sendiri. Konsep human interest juga digunakan agar website ini lebih menggambarkan suasana kegiatan perkuliahan yang dilakukan di Universitas Telkom. Terkait konsep media dan visual yang akan digunakan adalah media responsif yang dapat diakses dengan mudah melalui perangkat desktop maupun mobile dengan mudah, didukung dengan visual yang mengacu kepada brand identity dari Universitas Telkom itu sendiri. Di antaranya adalah penggunaan font Calibri (Gambar 9), serta penerapan warna yang sesuai dengan identitas Universitas Telkom (Gambar 10).

\section{ABCDEFGHIJKLMNOPQRSTUVWXYZ ABCDEFGHIJKLMNOPQRSTUVWXYZ abcdefghijklmnopqrstuvwxyz 0123456789 abcdefghijklmnopqrstuvwxyz 0123456789}

Gambar 9. Font Calibri dan Calibri Bold Sumber: Dokumentasi peneliti

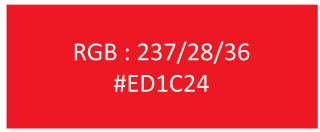
\#ED1C24
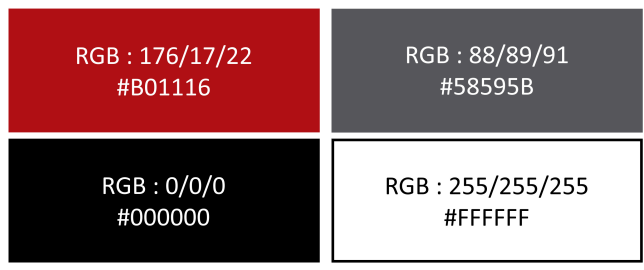

Gambar 10. Warna identitas Universitas Telkom Sumber: Dokumentasi peneliti

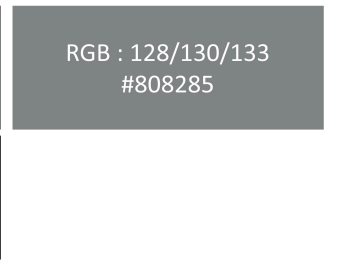

\section{Hasil Perancangan}

Hasil dari perancangan yang dilakukan adalah sebuah media digital yaitu website yang didesain dapat bekerja secara responsif. Website ini dapat diakses baik melalui perangkat desktop, tablet, maupun mobile (Gambar 11, Gambar 12, dan Gambar 13).

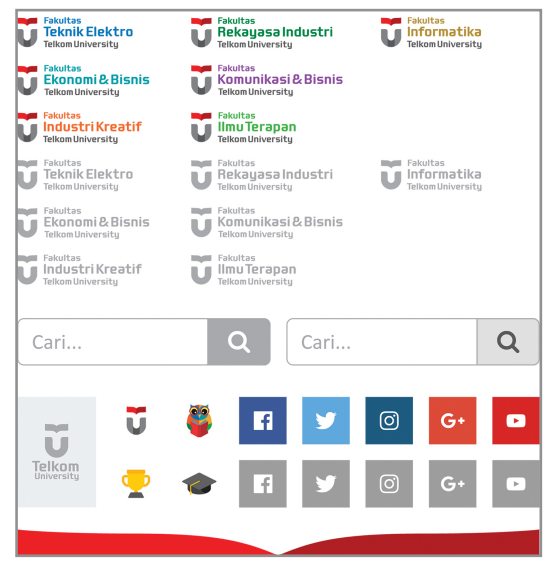

Gambar 11. Elemen visual website hasil perancangan Sumber: Dokumentasi peneliti 


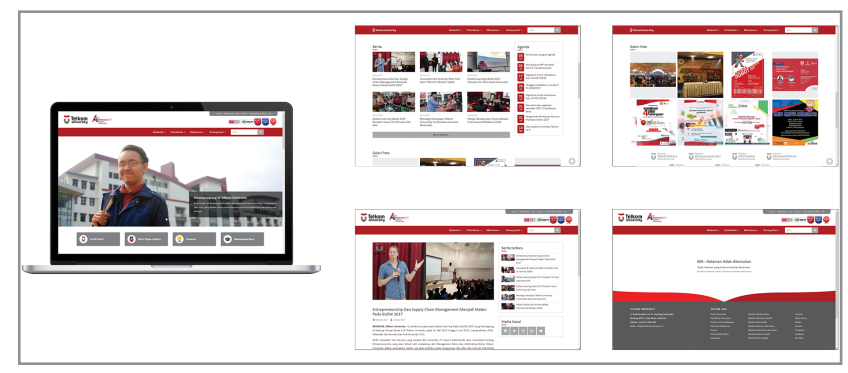

Gambar 12. Hasil perancangan halaman website versi desktop Sumber: Dokumentasi peneliti

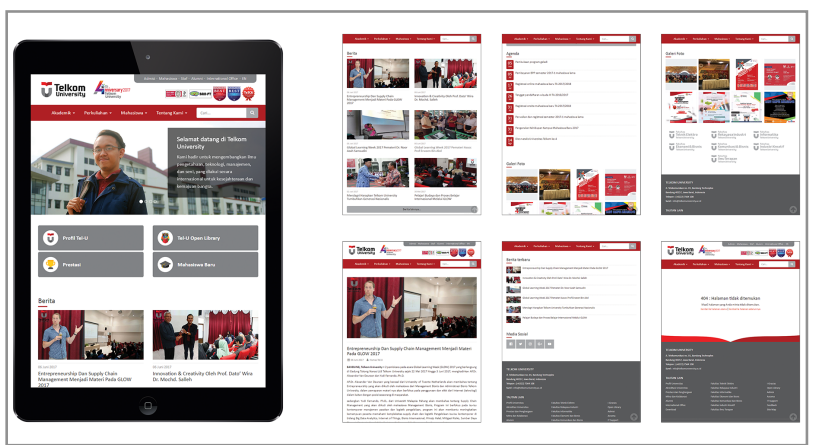

Gambar 13. Hasil perancangan halaman website versi tablet Sumber: Dokumentasi peneliti

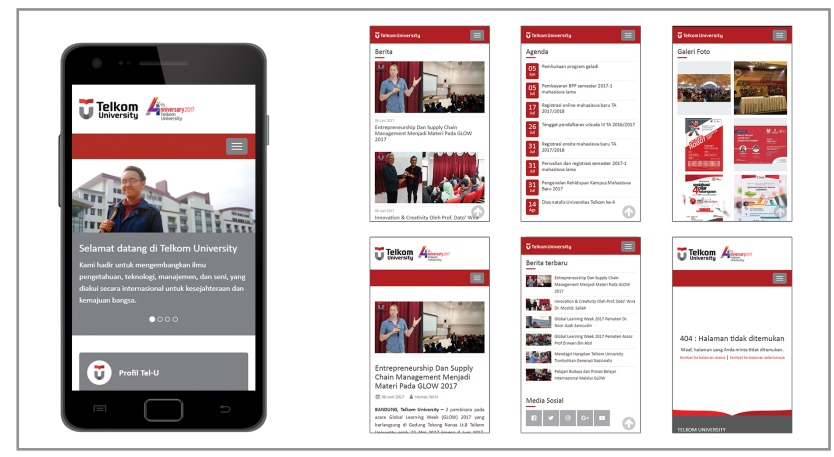

Gambar 14. Hasil perancangan halaman website versi mobile Sumber: Dokumentasi peneliti

\section{Pengujian Produk}

Guna menguji keberhasilan dari hasil perancangan yang telah dilakukan, produk kemudian diuji oleh tiga orang responden yang merupakan target audience dari website Universitas Telkom. Hasil pengujian tersebut kemudian dibandingkan dengan hasil penilaian terhadap website Universitas Telkom sebelum perancangan, dan terlihat adanya peningkatan nilai kepuasan pada website tersebut (Tabel 1). 
Tabel 1. Hasil pengujian website Universitas Telkom

\begin{tabular}{|c|l|c|c|c|c|}
\hline \multirow{2}{*}{ No. } & \multicolumn{1}{|c|}{ Pernyataan } & \multicolumn{1}{|c|}{$\begin{array}{c}\text { Sebelum } \\
\text { Perancangan }\end{array}$} & \multicolumn{3}{|c|}{ Setelah Perancangan } \\
\cline { 4 - 6 } & & Responden 1 & Responden 2 & Responden 3 \\
\hline 1 & $\begin{array}{l}\text { Anda merasa mudah dalam memperoleh informasi yang dibutuhkan } \\
\text { dalam website Tel-U. }\end{array}$ & Tidak Setuju & Setuju & Sangat Setuju & Setuju \\
\hline 2 & Informasi kontak mudah ditemukan dalam website Tel-U. & Setuju & Sangat Setuju & Sangat Setuju & Sangat setuju \\
\hline 3 & $\begin{array}{l}\text { Menu-menu utama dalam website Tel-U sudah jelas dan mudah } \\
\text { ditelusuri. }\end{array}$ & Tidak Setuju & Sangat Setuju & Sangat Setuju & Setuju \\
\hline 4 & $\begin{array}{l}\text { Menurut Anda warna yang digunakan pada website Tel-U sudah } \\
\text { cukup nyaman. }\end{array}$ & Tidak Setuju & Sangat Setuju & Sangat Setuju & Setuju \\
\hline 5 & $\begin{array}{l}\text { Menurut Anda, tingkat keterbacaan dari informasi teks dalam } \\
\text { website Tel-U sudah baik. }\end{array}$ & Tidak Setuju & Sangat Setuju & Sangat Setuju & Setuju \\
\hline 6 & $\begin{array}{l}\text { Gambar atau foto yang terdapat dalam website Tel-U memancing } \\
\text { Anda untuk menelusuri lebih lanjut. }\end{array}$ & Tidak Setuju & Sangat Setuju & Setuju & Sangat setuju \\
\hline 7 & $\begin{array}{l}\text { Anda merasa nyaman dengan model pengelompokan informasi } \\
\text { yang ada dalam halaman awal website Tel-U. }\end{array}$ & Tidak Setuju & Sangat Setuju & Sangat Setuju & Sangat setuju \\
\hline 8 & $\begin{array}{l}\text { Icon atau ilustrasi pada halaman website Tel-U sudah cukup jelas } \\
\text { dan dapat diprediksi isinya. }\end{array}$ & Tidak Setuju & Sangat Setuju & Sangat Setuju & Setuju \\
\hline
\end{tabular}

Sumber: Dokumentasi peneliti

Pada tabel 1, dapat terlihat perbandingan antara kepuasan pengguna terhadap website

Universitas Telkom dari sebelum dan juga setelah perancangan. Terdapat kenaikan nilai kepuasan pada setiap aspek yang diujikan kepada target audience, menandakan bahwa perancangan ulang yang telah dilakukan telah berhasil meningkatkan nilai user experience dari website Universitas Telkom.

\section{PENUTUP}

Berdasarkan penelitian dan kegiatan perancangan yang telah dilakukan, dapat ditarik kesimpulan bahwa untuk merancang user interface pada website sebagai media informasi Universitas Telkom untuk meningkatkan user experience harus dimulai dari fungsi dan tujuannya dalam memberikan informasi kepada masyarakat luas, dibalut dengan brand Universitas Telkom melalui media informatif dengan visual yang lebih menekankan pada kualitas serta keterbacaan kontennya apabila diakses melalui berbagai jenis perangkat yang dapat memudahkan pengguna untuk mencari informasi.

\section{DAFTAR PUSTAKA}

Adamson, A.P. (2006). Brand Simple. New York: Palgrave Macmillan.

Bank, C. dan Cao, J. (2015). Web UI Design Best Practices. UXPin. diakses dari https://www.uxpin.com/studio/ebooks/web-ui-design-best-practices/.

Cao, J., et al. (2015). White Space in Web UI Design - Mastering the Power of Nothing. UXPin. diakses dari https://www.uxpin.com/studio/ebooks/mastering-white-space-web-ui-design/. 
Faizal, M., et al. (2016). Penggunaan Website Portal Berita sebagai Media Penyampaian Informasi Universitas Telkom. Iaporan penelitian, Universitas Telkom.

Galitz, W.O. (2007). The Essential Guide to User Interface Design : An Introduction to GUI Design Principles and Techniques. Indianapolis: Wiley Publishing.

Garrett, J.J.(2011). The Elements of User Experience : User-Centered Design for the Web and Beyond. Berkeley: New Riders.

KBBI.(2016). Arti kata fotografi. http://kbbi.web.id/fotografi. Diakses tanggal 13 Maret 2017.

Kusrianto, A. (2009). Pengantar Desain Komunikasi Visual. Yogyakarta: Penerbit Andi.

Republik Indonesia. (2001). Undang-Undang Nomor 15 Tahun 2001 tentang Merek. Jakarta: Sekretariat Negara.

Soewardikoen, D.W.(2013). Metodologi Penelitian Visual, dari Seminar ke Tugas Akhir. Bandung: Dinamika Komunika.

Suryanto.(2015). Pengantar Ilmu Komunikasi. Bandung: Pustaka Setia.

Suyanto, A.H.(2009). Step by Step Web Design Theory and Practices. Yogyakarta: Penerbit Andi.

Treder, M. (2013). UX Design for Startups. UXPin. diakses dari https:// www.uxpin.com/studio/ebooks/ux-design-for-startups/.

Widyatama, R. (2011). Teknik Menulis Naskah Iklan. Yogyakarta: Cakrawala.

Williams, B.K dan Sawyer, S.C.(2007). Using Information Technology: Pengenalan Praktis Dunia Komputer dan Komunikasi. Yogyakarta: Penerbit Andi. 